\title{
DE ONDERNEMING EN DE ECONOMISCHE ORDE
}

\author{
door Dr. C. A. Koopman
}

\section{Economische orde en centralisatie}

Men kan niet spreken over het oplossen van belangrijke economische vraagstuk. ken zoals werkloosheid en inflatie zonder zich bezig te houden met de economische orde, het systeem waarbinnen de economische processen zich voltrekken.

Ter gelegenheid van zijn inauguratie wees Ellman (1) er kort geleden op dat autoritaire stelsels heel goed in staat zijn de werkloosheid op te heffen. Ook Key. nes bracht dit in het slothoofdstuk van de General Theory naar voren (2). Beiden voegen er echter aan toe dat dit gebeurt ten koste van efficiency en persoonlijke vrijheid, hetgeen volgens Keynes een te hoge prijs is.

Keynes' economisch denken is in sterke mate ethisch bepaald. Hoewel voort. gekomen uit de Victoriaanse traditie noemt hij zichzelf, onder invloed van de fi losoof G. E. Moore, een ,immoralist”, die het menselijk handelen in de eerste plaats beoordeelt naar de gevolgen ervan. De bestemming van de mens is, meent hij, om in vrijheid te genieten van de goede dingen die het leven biedt en werk loosheid is onaanvaardbaar omdat de mens daardoor van die bestemming wordt verwijderd. Vandaar dat in het economisch denken van Keynes na 1932 het veilig stellen van de werkgelegenheid door het op een voldoende hoog niveau hand. haven van zowel de consumptieve vraag als de investeringsvraag centraal staat.

Deze doelstellingen acht hij van zo wezenlijk belang voor individu en samen. leving dat hij als liberaal bereid is ter verwezenlijking ervan de positie van de overheid in het economisch bestel aanzienlijk te versterken. In het slothoofdstuk van de General Theory zegt hij dan ook dat de overheid een sturende invloed moet uitoefenen op de consumptieneiging door middel van het belastingstelsel, het vaststellen van de rentevoet en andere middelen en dat omvangrijke socialisatie van de investeringen in de toekomst het enige middel zal blijken te zijn om een situatie van (bij benadering) volledige werkgelegenheid te garanderen.

Daar komt nog bij dat theorieën omtrent het marktgedrag steeds minder re. levant worden en dat machtsconcentraties op markten - zowel goederenmarkten als de arbeidsmarkt - een zodanige rol spelen dat slechts de overheid in staat is voldoende tegenspel te bieden. In een periode van sterke economische groei, zoals de zestiger jaren, treedt deze machtsvorming niet zo duidelijk aan de dag, maar zodra de groei stagneert trachten machtsgroepen hun positie te consolideren of zelfs nog te verbeteren, hetgeen dan alleen maar kan geschieden ten koste van andere groepen. De machtsstrijd die dan ontstaat bedreigt niet alleen een rede lijke en rechtvaardige inkomensverdeling en daarmee de omvang van de effec tieve vraag, maar vormt tevens een gevaar voor het economisch bestel als geheel en het niveau van het nationaal inkomen. Ook hier is het slechts de overheid die in staat is onheil te voorkomen. 


\section{Het politiek relevant maken van de economische theorie}

Toenemende bemoeienis van de overheid met macro-, meso- en zelfs micro.economische problemen houdt echter het gevaar in van het ontstaan van logge, bureaucratische structuren, waarbinnen nieuwe vormen van machtsstrijd tot ont. wikkeling komen. Economen mogen dit gevaar niet veronachtzamen en zullen zich, naarmate de overheidstaken toenemen, meer moeten bezig houden met het politiek relevant maken van de economische theorie, hetgeen Keynes zijn leven lang heeft gedaan. Dit geldt vooral als het gaat om het oplossen van de grote economische vraagstukken als werkloosheid en inflatiebestrijding. In een brief van december 1944 zegt Keynes: „The task of keeping efficiency-wages reasonably stable (I am sure that they will creep up steadily in spite of our best efforts) is a political rather than an economic problem". (3) (cursivering van mij. K.)

Naar aanleiding van dit citaat stelt Aubrey Jones de vraag: Wat bedoelde Keynes hier met het woord politiek? (4) Alvorens deze vraag te beantwoorden wijst hij erop dat werknemers die, in Marxistische terminologie uitgedrukt, zijn ver. vreemd van zichzelf en van hun medemensen niets anders overblijft dan op grond van gemeenschappelijke belangen, als lotgenoten een verbond te sluiten. De machtspositie die hiervan een gevolg is leidt tot loonstijgingen. De omstandigheid dat "fixprice" markten steeds meer de plaats innemen van "flexprice” markten versterkt de concurrentiepositie van ondernemers en stelt hen in staat de loonkostenstijging door te berekenen aan de consument.

Volgens Jones is het fundamentele politieke probleem het binnen de onder. neming herstellen van de relatie leiders.geleiden en het in ruimer verband opnieuw wekken van begrip voor het algemeen belang. Hij pleit daartoe voor een ,job evaluation scheme" voor ondernemingen met meer dan een bepaald aantal werknemers, waarbij de beloningen worden vastgesteld naar de relatieve bete. kenis van de onderscheiden werkzaamheden.

Hoewel Jones het probleem op zichzelf wel juist stelt meen ik dat de oplossing die hij aanbeveelt maatschappelijk en politiek achterhaald is. In ontwikkelde economieën wordt de relatie tussen inkomen en geleverde prestatie steeds minder relevant zodat ,job evaluation", hoe belangrijk op zichzelf ook, geen oplossing kan bieden voor de meest belangrijke economische en politieke vraagstukken.

\section{Economische orde en decentralisatie}

In het reeds eerder genoemde slothoofdstuk van de General Theory beveelt Key. nes ons een oplossing aan die mijns inziens meer perspectieven opent dan die van Jones. Hij zegt daar: "The advantage to efficiency of the decentralization of decisions (cursivering van mij. K.) and of individual responsibility is even greater, perhaps, than the nineteenth century supposed, and the reaction against the appeal to selfinterest may have gone too far." Decentralisatie van de besluitvorming biedt, zegt hij, de beste mogelijkheden om ,the variety of life, which emerges precisely from this extended field of personal choice" te waarborgen. (5)

Er zijn in onze samenleving, naast de in de eerste paragraaf beschreven cen. traliserende tendenties, factoren werkzaam die ons sturen in de richting van meer gedecentraliseerde besluitvorming.

Bij meer dan één gelegenheid heb ik erop gewezen dat in een volwassen parlementaire democratie de invloed van burgers niet kan worden beperkt tot het 
periodiek kiezen van hun vertegenwoordigers in de politieke organen. De behoef. te om mee te denken, mee te spreken en mee te beslissen in zaken die hen persoonlijk aangaan doet burgers vragen naar aanvullingen op onze parlementaire democratie ten einde deze behoefte te kanaliseren en institutionaliseren. (6)

Dit geldt uiteraard ook voor de burgers als werknemers en levert dan de roep om bedrijfsdemocratisering op. Het geldt ook voor alle andere leefsituaties, zoals die waarin men als consument naar voren treedt. Beslissingen genomen op grote afstand van de consument - en dan nog veelal op grond van sterk vereenvoudigde gedragsconcepties staan slechts in een verwijderd verband tot de werkelijke behoeften en wensen van consumenten. Volgens economen valt het allemaal wel mee omdat de markt een soort stemmachine is waarin de guldens van de consumenten als stemmen worden geteld. De werkelijkheid is echter anders.

Scitovsky toont aan dat onze technologisch hoog ontwikkelde samenleving wel. iswaar ongekende mogelijkheden schept, maar ons tevens zodanig dringt in de richting van standaardisatie en eenvormigheid dat ons vermogen om van de tech. nologische verworvenheden op creatieve wijze te genieten in ernstige mate wordt aangetast. (7)

Als we bovendien in acht nemen dat het aantal goederen en diensten toe. neemt en dat de informatie ten behoeve van consumenten uiterst gebrekkig is zal duidelijk zijn dat consumenten heel wat minder invloed hebben op hun con sumptiepatroon dan veelal wordt verondersteld. De toenemende behoefte van consumenten om de economische besluitvorming naar zich toe te halen, dus te decentraliseren, is een factor waarmee we in de toekomst terdege rekening zullen moeten houden.

$\mathrm{Er}$ is nog een andere factor in onze samenleving werkzaam die decentralise rend werkt.

De doelmatigheid van een besluitvormingsproces staat of valt met de hoeveel. heid en kwaliteit van de beschikbare informatie. Centralisatie van besluitvor. ming, vooral van die op het gebied van micro-economische processen, betekent het verzamelen van onvoorstelbaar grote hoeveelheden gegevens op centraal ni. veau. Omdat het verwerken van deze massa's gegevens het fysiek vermogen van de besluitvormers te boven gaat betekent dit dat selectie van informatie nodig is, hetgeen ten gevolge heeft dat grote - en dikwijls ongecontroleerde - macht wordt gelegd in handen van degenen die de informatiezeef hanteren.

Niels Hammer-Jespersen pleit dan ook voor het gebruiken van gedecentrali. seerde allocatiemodellen, zodat beslissingen worden genomen op niveaus waar de vereiste informatie reeds aanwezig is en de overdracht van gedetailleerde in. formatie tot een minimum kan worden beperkt. (8)

\section{Economie en politiek}

Aangezien het economisch handelen in steeds sterker mate door politieke beslis. singen in plaats van door marktprocessen wordt bepaald is het voor het vinden van oplossingen voor de actuele vraagstukken noodzakelijk om economie en politiek te integreren of, zoals ik in het voorgaande opmerkte, de economische theo. rie politiek relevant te maken.

De eerste vraag die daarbij aan de orde komt is die van de afbakening van de taken van de overheid en van particulieren en het vaststellen van het verband 
ertussen. Dit betekent dat als men van mening is dat een aantal belangrijke pro. blemen met behulp van de overheid zullen moeten worden opgelost, terwijl de overheid daartoe niet voldoende is toegerust, we die problemen niet onopgelost moeten laten maar de economische orde zodanig moeten wijzigen dat de over. heid die taken wel aankan.

De twee belangrijkste economische vraagstukken die thans om een oplossing vragen zijn de werkloosheid en de inflatie. Hoewel het binnen het beperkte kader van dit artikel niet mogelijk is om uitvoerig op beide vraagstukken in te gaan zijn enkele algemene opmerkingen onmisbaar.

De belangrijkste middelen om de werkgelegenheid veilig te stellen zijn mijns inziens het op selectieve wijze stimuleren van de effectieve vraag en het beheer. sen van de inkomensontwikkeling en verdeling.

Wat het consumptieve deel van de effectieve vraag betreft zal in de ontwikkel. de landen vooral aandacht moeten worden besteed aan de behoefte aan creatie. ve produkten') die in de afgelopen periode van onstuimige materiële groei op de achtergrond is geraakt. Daar het in een ontwikkelde democratie onaanvaardbaar is om burgers een consumptiepatroon op te dringen of zelfs dwingend voor te schrijven behoort het onder meer tot de taak van de overheid om consumenten meer bewust te maken van hun creatieve behoeften en de betekenis ervan voor hun welzijn. Een selectief groeibeleid dient te zijn gebaseerd op normen ontleend aan een goed doordacht consumptiebeleid. (9)

Bovendien zal ter vergroting van de effectieve vraag het Keynesiaanse instru. ment van de inkomensnivellering verder moeten worden gehanteerd en dan niet alleen in de binnenlandse situatie. Ten gunste van zowel de rijke als de arme lan den dient een rechtvaardiger inkomensverdeling tussen ontwikkelde en ontwik. kelingslanden met kracht te worden bevorderd.

Wat de investeringsvraag betreft zal een stelsel van indicatieve planning, ge. baseerd op strategieën die tot stand zijn gekomen door nauwe samenwerking van overheid, bedrijfsleven en consumentenorganisaties nodig zijn. Door bij de uit. werking en uitvoering van de plannen decentralisatie van de besluitvorming te betrachten kan de verantwoordelijkheid zodanig worden verdeeld over de participanten dat een bewuste afweging van alternatieven plaatsvindt.

Voor zover het particulier initiatief tekortschiet bij het realiseren van voldoen. de werkgelegenheid dient de overheid zelf te investeren, in het bijzonder op gebieden die te maken hebben met de creatieve behoeften.

Het tweede grote vraagstuk dat om een oplossing vraagt is dat van de inflatie. Voor een kleine, open economie als de Nederlandse bieden flexibele wisselkoer. sen geen oplossing. Voor zover inflatie is geïmporteerd en gelijke tred houdt met de belangrijkste economische partnerlanden kunnen ethisch en economisch on. gewenste consequenties worden gecorrigeerd langs fiscale weg. Het rapport Hof. stra biedt daartoe een deugdelijke grondslag. (10)

Daarnaast zal de overheid er als grootste werkgever niet aan kunnen ontko. men om zowel ten behoeve van de werkgelegenheid als het beteugelen van de

\footnotetext{
1) Het begrip creatieve produkten wordt hier gebruikt in tegenstelling tot defensieve produkten. De laatste dienen om on. aangename gewarwwordingen als honger, dorst, koude en pijn weg te nemen en zijn in beginsel verzadigbaar. De eerste dienen om positieve gewaarwordingen teweeg te brengen en zijn onverzadigbaar. Zie Tibor Scitovsky: The joyless economy; Oxford, London, New York 1977, p. 108112.
} 
inflatie een inkomensbeleid te voeren, hetgeen niet per sé hoeft te gebeuren in de vorm van centraal dwingend voorgeschreven maatregelen.

In een globaal geplande economie is het mogelijk overleg- en beslissingsstructuren te creëren waarin, binnen door de centrale overheid geschapen kaders, op verschillende niveaus gedecentraliseerde beslissingen worden genomen. De plaats van de onderneming in deze structuur komt nog uitvoerig aan de orde.

Desondanks zal in een dynamische samenleving een niet onaanzienlijke hoe. veelheid structurele en frictiewerkloosheid onvermijdelijk zijn. Het blijft dus van belang dat de structuur van de arbeidsmarkt wordt verbeterd, de beschikbare arbeid rechtvaardig wordt verdeeld en dat een goed stelsel van sociale voorzienin gen een aanvaarbaar alternatief vormt voor onvrijwillige werkloosheid. Die aanvaardbaarheid eist dat aan een belangrijke voorwaarde is voldaan. Eén van de meest wezenlijke behoeften van de mens is namelijk die aan maatschappelijke er. kenning en waardering, een behoefte die in het verleden veelal werd bevredigd door middel van het werk en de daarmee verband houdende plaats in de samen leving. Nu door de veranderde structuur van die samenleving arbeid deze functie in steeds geringere mate vervult zullen we nieuwe mogelijkheden tot stand moeten brengen om de bevrediging van deze essentiële behoefte mogelijk te maken, hetgeen slechts kan door middel van politieke oplossingen. In dit verband volsta ik met te verwijzen naar de uitvoerige discussie rond de Contourennota.

\section{Het op elkaar afstemmen van centraliserende en decentraliserende tendenties in de maatschap- pelijke orde}

In de voorgaande paragrafen hebben wij vastgesteld dat in de huidige samenle. ving enerzijds factoren werkzaam zijn die ons drijven in de richting van centralisatie, terwijl we anderzijds tegelijkertijd factoren kunnen waarnemen die ons in de richting van decentralisatie sturen. Beide groepen factoren beïnvloeden de structuur van de besluitvorming, hetgeen betekent dat impulsen van bovenaf en van onderop hun invloed doen gelden en elkaar op allerlei niveaus in het maat. schappelijk stelsel ontmoeten en op elkaar moeten worden afgestemd. In mijn studie over onderwijsplanning heb ik hierover gezegd: „Wij worden hier gecon fronteerd met het wellicht meest fundamentele probleem bij het structureren van welk besluitvormingsproces dan ook." (11)

$\mathrm{Bij}$ het zoeken naar een oplossing verdient het aanbeveling de economische orde te beschouwen als een sub systeem van het maatschappelijk systeem omdat het systeemdenken ervan uitgaat dat de relaties tussen de elementen van een or. ganisatie moeten worden zichtbaar gemaakt. Alleen grondige kennis van het relatiepatroon is een goede grondslag voor het plannen van een organisatie. Daar. bij ontdekt de systeemanalist in de praktijk meestal eerst dat de doelstellingen van het te plannen systeem niet of slechts uiterst gebrekkig zijn geformuleerd.

Het is dan ook verstandig om bij het op elkaar afstemmen van centraliserende en decentraliserende factoren te beginnen met het formuleren van de doelstel. lingen, waarbij kan worden uitgegaan van het referentiekader van het overheids beleid zoals dat onder meer door de Commissie voor de Ontwikkeling van de Be. leidsanalyse (COBA) is geformuleerd. Maar we wijzen er met nadruk op dat het formuleren van de doelstellingen zelf een politieke daad is die dus dient te worden verricht door Regering en Staten Generaal. 
Uit het referentiekader kunnen met behulp van regeringsverklaring, beleidsno. ta's en dergelijke algemene doelstellingen worden afgeleid voor een bepaald be. leidsterrein en daaruit worden dan weer de operationele doelstellingen verkregen. Het geheel vormt dan de zogenaamde doelstellingenstructuur. Door een proces van verfijning en concretisering kan uit de doelstellingenstructuur een pro. grammastructuur worden afgeleid die via een aantal beleids- en uitvoeringsniveaus aangeeft welke activiteiten ter bereiking van de gestelde doeleinden vereist zijn. Voorbeelden van doelstellingenschema's voor onderwijs en voor culturele zaken zijn te vinden respectievelijk in mijn studie over onderwijsplanning (12) en in het driemaandelijks bericht Beleidsanalyse van de COBA. (13)

Ten behoeve van deelgebieden van het programma kunnen kosten-baten en kosten-effectiviteitsanalyses worden opgesteld, bij voorkeur voor een aantal alter. natieve oplossingen, zodat beslissingen kunnen worden genomen op grond van voldoende en adequate informatie en in het kader van een doelgericht beleid. Een voorbeeld van zo'n analyse ten behoeve van de maatschappelijke wenselijkheid van een LNG.project (aanvoer vloeibaar aardgas) is gepubliceerd in een recent nummer van Beleidsanalyse. (14)

Het is wel gewenst om aan de formulering van de doelstellingen een systematische inventarisatie of beschrijving van het te plannen beleidsgebied te doen voorafgaan. Door die inventarisatie worden immers de eerdergenoemde relatiepatronen van dat beleidsgebied zichtbaar die voor het nemen van de juiste be leids- en uitvoeringsbeslissingen gekend moeten worden. Het is mijn stellige over. tuiging dat door de overheid aan individuele ondernemingen verstrekte financië. le hulp niet of zeer weinig effectief is geweest omdat de relatiepatronen onbekend waren, waardoor men niet of onvoldoende wist wat er in de opeenvolgende "spending rounds" zou gaan gebeuren en welke lekken - denk bij voorbeeld aan het buitenland-lek - zich zouden voordoen.

\section{Planning van het economisch bestel}

Bij het bestuderen van planningsystemen kunnen we dankbaar gebruik maken van een boekje van Turner en Collis dat een interessante typologie van de in ver. schillende landen voorkomende planningstelsels ontwikkelt op grond van de mate van centralisatie en concentratie.

De classificatie is gebaseerd op de volgende vijf criteria:

- de structuur van de informatiesystemen;

- de hiërarchie van de besluitvorming;

- de mate waarin preferenties van consumenten een rol speelt;

- de administratieve deconcentratie, d.w.z. de mate waarin de besluitvorming is gedelegeerd naar lagere administratieve eenheden;

- de parametrische deconcentratie, waarmee bedoeld wordt de mate van de. legatie van besluitvorming naar individuele besluitvormers binnen het kader van centraal vastgestelde parameters. (15)

Op grond van deze criteria komen Turner en Collis tot een schema waarin wij, ongeveer in het midden, onmiddellijk na elkaar het Joegoslavische en het Franse planningstelsel aantreffen, die beide zeer interessante elementen bevatten als het gaat om het op elkaar afstemmen van centraliserende en decentraliserende tendenties. 
In Frankrijk, dat als de bakermat van de indicatieve planning moet worden be schouwd, spelen sedert de zestiger jaren planning overeenkomsten tussen overheid en bedrijfsleven een belangrijke rol. Deze overeenkomsten hebben verschillende vormen aangenomen waarvan Turner en Collis de volgende noemen:

- weinig gedetailleerde quasi-contracten uit de vroege zestiger jaren voor het verschaffen van de financiële middelen voor speciale investeringen; zij heb. ben weinig ingang gevonden;

- programma-contracten waarbij ondernemingen toestemming krijgen hun prijzen te verhogen ten einde investeringen te financieren, mits produktie, in. vesteringen en exportplannen zijn afgestemd op de doelstellingen van het plan;

- gezamenlijke actieprogramma's voor bijvoorbeeld het moderniseren en rationaliseren van bepaalde bedrijfstakken. (16)

In dit verband is het wellicht interessant om kennis te nemen van het rapport van de gemengde ambtelijke werkgroep „Onderzoek Uitbreidingsmogelijkheden Hoogovens IJmuiden" waarin, met als uitgangspunt een denkmodel van Hoog. ovens, de consequenties worden onderzocht van een eventuele uitbreiding in de jaren ' 80 voor de nationaal. en regionaal-economische betekenis van Hoogovens, de arbeidsmarkt, de woningvoorziening, het milieu, de verkeersinfrastructuur en het energieverbruik. (17)

Het rapport begint met de volgende woorden: „In toenemende mate worden ontwikkelingsmogelijkheden van bedrijven - en zeker van een groot bedrijf als Hoogovens IJmuiden BV (Nederlandse partner in het Estelconcern) - bepaald door externe factoren, die op het bedrijf inwerken en die van het bedrijf naar buiten gaan." Het rapport vervolgt met de mededeling dat bij het gebruikelijke over leg dat Hoogovens met de overheid voert steeds meer blijkt dat overleg op basis van deelgebieden, korte termijn ontwikkelingen en incidentele gebeurtenissen ontoereikend is. (18)

Voor Hoogovens was dit aanleiding om in een tweetal brieven gericht aan het College van Gedeputeerde Staten van Noord.Holland, die als bijlagen 1 en 2 aan het rapport zijn toegevoegd, de ontwikkelingsproblematiek met betrekking tot de nieuwbouw van het bedrijf in de tachtiger jaren neer te leggen. In de eerste brief wordt onder meer opgemerkt dat belangrijke investeringsbeslissingen slechts kunnen worden genomen wanneer er een duidelijk zicht bestaat op de externe condities die aan de bedrijfsvoering worden gesteld en dat deze externe condities in belangrijke mate door de overheid worden beheerst. (19)

De laatste zinsnede is een gerede aanleiding om de plaats van de onderneming in het economisch bestel nader te bezien.

\section{De doelstellingen van de onderneming}

Sprekend over de doelstellingen van de onderneming maakt Bouma onderscheid tussen het holistisch ondernemingsbegrip, waarbij slechts één besluitvormer ac. tief is en de overige bedrijfsgenoten zich volledig in dienst stellen van de topleider, en gedragsconcepties, waarbij sprake is van een geheel van samenhangende ac. tiviteiten, waartoe door meerdere subjecten wordt besloten, welke subjecten worden gedreven door ten dele strijdige belangen. (20)

In het laatste geval spreekt Bouma van doelstellingen van de onderneming die 
via onderhandelingen zijn afgeleid uit de doelstellingen van verschillende groe pen participanten. (21)

In zijn „Inleiding tot de tiende druk van het Leerboek der Bedrijfseconomie van J. L. Meij" wijst Bouma erop dat een belangrijk gedeelte van de theoretische be. schouwingen over de gedragingen van bedrijfshuishoudingen berust op de ver. onderstelling dat de groep participanten wier doelstelling overheersend is bestaat uit de eigenaren en dat deze eigenaren streven naar het verkrijgen van inkomen, hetgeen wil zeggen dat de uitkeerbare winst het ondernemingsdoel is. (22)

In de volgende paragrafen behandelt Bouma andere ondernemingsdoelstellin. gen zoals de verkoopopbrengsten, het streven naar inkomen ten behoeve van alle bedrijfsgenoten, het bevredigen van machtsdrift en eerzucht. Tenslotte, zegt hij, „komt men de opvatting tegen, dat de onderneming streeft naar het opbouwen en in stand houden van goede betrekkingen met werknemers, afnemers, overheid en anderen (goede "public relations") en naar het creëren en bestendigen van werkgelegenheid voor een deel van de beroepsbevolking. Het is niet moeilijk om de opsomming van dergelijke ,sociale" doelstellingen uit te breiden." (23)

Deze reeks van doelstellingen overziende constateren wij een overgang van winstmaximalisatie als primair ondernemingsdoel naar doelstellingen als het op efficiënte wijze voorzien in maatschappelijke behoeften en het scheppen en onderhouden van werkgelegenheid, waarbij een redelijke omvang van het rendement is teruggebracht tot een randvoorwaarde voor de continuiteit van de onderneming.

Een enigszins andere formulering treffen we aan bij Eric Rhenman die onder. scheid maakt tussen de begrippen doelstelling en functie en meent dat de term doelstelling altijd betrekking heeft op opvattingen van een individu of van een groep. In deze gedachtengang kunnen we niet spreken van de doelstellingen van een organisatie. Bij een onderneming bijvoorbeeld zal men moeten aangeven of het gaat om doelstellingen van het management, van de vermogensverschaffers, van de werknemers of welke andere groep ook. De term doel mogen we volgens Rhenman dus niet gebruiken zonder nadere kwalificatie of klassificatie. Een onderneming heeft alszodanig dan ook geen doel maar een functie, die wordt be. paald door groepen of individuen binnen de onderneming die hun doelstellingen tot gelding weten te brengen. (24)

Om ons niet te ver te verwijderen van het gangbare spraakgebruik wil ik in het vervolg van dit artikel spreken over doelstellingen van de onderneming, waarbij we ons ervan bewust dienen te zijn dat deze de opvattingen weerspiegelen van de groep die binnen de onderneming de zeggenschap uitoefent of het resultaat zijn van een compromis waarin de opvattingen van een aantal machts. groepen met elkaar zijn verzoend.

In ieder geval is duidelijk dat twee aspecten bepalend zijn voor de rol, functie of doelstellingen van een onderneming in de samenleving.

In de eerste plaats gaat het erom in welk maatschappelijk kader de onderneming moet functioneren, of anders gezegd welke externe factoren bepalend zijn voor de besluitvorming binnen de onderneming.

In de tweede plaats is de besluitvormingsstructuur binnen de onderneming zelf van grote betekenis.

Wij zullen de ontwikkeling van deze beide aspecten aanduiden als de externe en de interne vermaatschappelijking van de onderneming. 


\section{De externe vermaatschappelijking van de onderneming}

De economische wetenschap heeft in de loop van haar bestaan theorieën ontwikkeld over het producentengedrag, waarbij producenten als „economische mensen" reageren op markt- en concurrentieverhoudingen.

Naarmate zich echter op markten meer of minder doorzichtige machtsverhou. dingen ontwikkelden en naarmate de beïnvloeding van het economisch bestel door de overheid toenam werden deze theorieën minder relevant.

Voor ondernemingen was het gevolg dat de externe factoren waarmee moet worden gerekend bij het opstellen van strategische en operationele plannen van karakter veranderden. Omdat deze factoren, voor zover ze door de overheid wor. den bepaald, geacht moeten worden via politieke beslissingen de wensen te weerspiegelen die in de samenleving voorkomen, kunnen we in dit verband spreken van de externe vermaatschappelijking van de onderneming. Nuchter bezien komt het erop neer dat de bewegingsvrijheid van ondernemingen in mindere mate door impulsen van de markt en in sterkere mate door van overheidswege gestelde kaders wordt bepaald.

In één van de vorige paragrafen heb ik erop gewezen dat deze kaders een meer of minder gedetailleerd en een meer of minder bindend karakter kunnen hebben en ik koos daarbij voor globale, indicatieve planning door de overheid, gecombineerd met het op ruime schaal toepassen van decentralisatie van de besluitvor. ming.

Men staat er weinig bij stil dat de ondernemingsgewijze produktie een in sterke mate gedecentraliseerd systeem is, waarbij aanvankelijk in beginsel het ordenend principe werd gevormd door het marktmechanisme. Aangezien het marktmechanisme als ordenend beginsel in de praktijk leidde tot maatschappelijk onaanvaardbare situaties, terwijl de veronderstelde-invloed van consumenten in werkelijkheid een te verwaarlozen factor was, zijn via de politieke besluitvorming nieuwe kaders tot stand gekomen, waarbinnen ondernemingen eveneens gede. centraliseerde beslissingen kunnen nemen.

In de huidige Nederlandse samenleving worden deze kaders onder meer be. paald door de Wet op de ruimtelijke ordening en de daarmee samenhangende streek en bestemmingsplannen, de Hinderwet, tal van fiscale wetten, deWet in vesteringsrekening en loonpolitieke maatregelen. Daar komt nog bij dat waar de werkgelegenheid in het geding is steun aan individuele ondernemingen tot de mogelijkheden behoort.

Het is mijn stellige overtuiging dat in Nederland een meer samenhangende be. nadering van al deze factoren in een stelsel van indicatieve planning, dat de rand. voorwaarden formuleert voor de planning van het economisch bestel, dringend nodig is. De wijze waarop thans allerlei soorten beslissingen op grond van verschillende wetten, los van elkaar worden genomen is niet bevorderlijk voor het totstandbrengen van een consistent en krachtig beleid. Door middel van plan ningovereenkomsten, waarin de randvoorwaarden worden vastgelegd voor in. dividuele bedrijven of groepen bedrijven (bedrijfstakken, sectoren van bedrijvig. heid of regio's), kan vervolgens de besluitvorming worden gedecentraliseerd. De eerder genoemde ambtelijke werkgroep met betrekking tot de uitbreiding van Hoogovens toont aan hoe langs deze weg bedrijfseconomische beslissingen bij voorbaat kunnen worden afgestemd op maatschappelijke behoeften en beperkingen. 
Een belangrijke eis die we daarbij moeten stellen is wel dat de gecreëerde over. legstructuren eenvoudig van aard zijn, zodat snel en efficiënt kan worden gewerkt. In dit verband is het zinvol te herinneren aan een column van de hand van P. A. de Ruiter, enkele jaren geleden verschenen in ESB onder de titel „SIR straks". (27)

De Ruiter wijst er daarin op dat opheffing van het vergunningenstelsel van de SIR tegelijk met invoering van de investeringsrekening het naar zijn opvatting zeer belangrijke subjectieve element van de toetsing van investeringen elimineert. Hij is een duidelijk voorstander van een vergunningenstelsel a la de Selectieve Investeringsregeling als eerste grove zeef, maar dan wel op zodanige wijze toegepast dat eindeloze en frustrerende procedures worden vermeden. Hij pleit daarom voor het creëren van regionale knelpuntenbureaus - een vorm van de. centralisatie dus - die op een vroeg tijdstip verplicht worden ingeschakeld in procedures voor vergunningenaanvragen voor bedrijfsvestiging of uitbreiding en die de besluitvormingsprocessen kunnen verbeteren en versnellen.

Ik ben het met hem eens dat de overheid, naarmate haar bemoeienis met het economisch bestel toeneemt, zodanige instrumenten moet scheppen en hanteren dat de slagvaardigheid bij het nemen van gedecentraliseerde economische beslis. singen is gewaarborgd.

\section{De interne vermaatschappelijking van de onderneming}

Efficiënt handelen is doelmatig handelen, hetgeen wil zeggen handelen gericht op verwerkelijking van de doelstellingen van de organisatie. Sedert het doel van een onderneming niet meer hoofdzakelijk bestaat uit winstmaximalisatie heeft het begrip efficiency in het bedrijfsleven dan ook een duidelijke verandering van inhoud ondergaan. De precieze inhoud van het begrip wordt bepaald door de groepen in de onderneming die hun doelstellingen tot gelding weten te brengen.

Rhenman wijst erop, maar we kunnen het ook zelf constateren, dat werknemers een groep vormen wier invloed op ondernemingsdoelen en ondernemingsbeleid groeiende is, al zijn het veelal nog wel het management en de specialisten die verantwoordelijk zijn voor de formulering van de voorgeschreven doelen. (25) Naast de traditionele doen nieuwe doeleinden hun intrede, terwijl thans het creë. ren van arbeidsplaatsen sterk op de voorgrond treedt.

Recent onderzoek heeft uitgewezen dat met betrekking tot het menselijk wel. zijn de behoefte aan maatschappelijke erkenning en waardering één van de meest essentiële behoeften is en dat deze behoefte in de meeste gevallen nog altijd via het werk en de daarmee verbonden contacten wordt bevredigd. (26) Hoewel in de geïndustrialiseerde landen de betekenis van iemands werk veelal wordt bepaald aan de hand van het inkomen dat hij eraan ontleent, blijft de werksituatie zelf van grote invloed op het welzijn van de meeste burgers. Het is dan ook niet verwonderlijk dat aan de werkomstandigheden steeds grotere aandacht wordt besteed en dat werknemers een grotere invloed op hun werk en werkomstandig. heden willen uitoefenen.

De wens tot democratisering van de arbeidsverhoudingen kan zich voordoen in verschillende vormen, waarbij twee vragen een rol spelen:

- Gaat het om democratisering bij de voorbereiding of bij de uitvoering van produktieprocessen? 
- Is er sprake van directe of indirecte democratie?

Als we ons voorlopig beperken tot de eerste vraag kunnen we vaststellen dat bei de vormen zich in de praktijk voordoen. In Joegoslavië is de ontwikkeling vooral gericht op zeggenschap bij de voorbereiding (planning) van produktieprocessen en bij de verdeling van het inkomen. In Zweden daarentegen is de democratise. ring gericht op de uitvoering van de produktieprocessen en staan werkoverleg en werkstructurering in het middelpunt van de belangstelling.

De tweede keuze, die tussen directe en indirecte democratie, houdt verband met de vraag of werknemers zelf meespreken en meebeslissen of dit overlaten aan hun gekozen vertegenwoordigers.

We kunnen het Joegoslavische zelfbestuur weer aanwijzen als voorbeeld van directe democratie, terwijl de Nederlandse ondernemingsraad de indirecte of ver. tegenwoordigende democratie representeert.

Een derde aspect bij dit alles is dat directe democratie, zowel bij de voorbereiding als bij de uitvoering van de produktieprocessen, een aanzienlijke mate van decentralisatie van de besluitvorming vereist. Vandaar dat Joegoslavische onder. nemingen zijn samengesteld uit zogenaamde Basisorganisaties van Verenigde $\mathrm{Ar}$. beid die elk \pm 300 werknemers tellen. Bij grotere eenheden zou van efficiënte besluitvorming geen sprake meer kunnen zijn. Dat dit ingrijpende eisen stelt met betrekking tot de coördinatie, de informatieverzorging en de controle, en dus voor de hele interne organisatie, spreekt vanzelf. Wie belang stelt in deze orga. nisatiestructuren kan in de beschikbare literatuur tal van beschrijvingen vinden. (28)

De vertegenwoordigende democratie kan ook functioneren in organisaties met sterk gecentraliseerde besluitvormingsstructuren, al moeten we bedenken dat de beslissingen dan ver verwijderd van belanghebbenden worden genomen zodat de besluitvormers licht vervreemden van hun achterban.

Aan welke vorm van democratisering wij dan ook de voorkeur geven, decen tralisatie van de besluitvorming blijft mijns inziens een belangrijke voorwaarde om belanghebbenden zoveel mogelijk bij beslissingen te betrekken en hen te mo. tiveren ten aanzien van hun rol in de organisatie.

\section{Samenvatting en conclusies}

In de paragrafen aan het begin van dit artikel heb ik geconstateerd dat in hoog ontwikkelde economieën factoren werkzaam zijn die ons tegelijkertijd dringen in de richting van centralisatie en van decentralisatie van de besluitvorming.

In het vervolg heb ik als mijn mening naar voren gebracht dat de centraliserende tendenties zullen leiden tot een meer planmatige aanpak in de vorm van een globaal, indicatief planningstelsel waarin, via de politieke organen, maatschappelijke voorkeuren tot uitdrukking worden gebracht. Door middel van planningovereenkomsten kunnen vervolgens de globale plannen naar ondernemin. gen, bedrijfstakken, sectoren van bedrijvigheid en regio's worden verbijzonderd, zodat zij de randvoorwaarden vormen ten behoeve van de ondernemingsplan. ning.

Anderzijds hebben we geconstateerd dat de toenemende behoefte van burgers in een volwassen parlementaire democratie om mee te denken, spreken en be

$m a b$ blz 374 
slissen als het gaat om hun werk-, woon- en leefsituatie decentralisatie van besluitvorming, ook binnen ondernemingen, nodig maakt.

De consequentie van dit alles is dat binnen ondernemingen centraliserende en decentraliserende tendenties elkaar ontmoeten en op ekaar moeten worden af. gestemd en de vraag rijst of het mogelijk is een zodanige ondernemingsstructuur te creëren dat aan beide tendenties recht wordt gedaan. De wensen die in de samenleving naar voren komen en via vertegenwoordigers in politieke organen op centraal niveau tot uitdrukking worden gebracht zullen van boven naar beneden, in een proces van verbijzondering, ,rijp” gemaakt moeten worden voor uitvoering. Het zou van weinig logica getuigen om daarbij het decentralisatieproces van de ondernemingsgewijze produktie te doen stoppen bij de grens van de onderneming. Het valt mij dikwijls op dat vurige voorstanders van de ondernemingsgewijze produktie, dus van decentralisatie van economische besluitvorming, uitermate inconsequent zijn en binnen de onderneming de meest centralistische besluitvormingsstructuren voorstaan.

In technologisch en politiek ontwikkelde parlementaire democratieën zal het proces van decentralisatie zich op natuurlijke wijze moeten kunnen voortzetten binnen de onderneming.

Wat ons land betreft ligt het mijns inziens voor de hand dat dit gebeurt zowel met betrekking tot de uitvoerende arbeid als bij de planning van de produktieprocessen. Het is mijn stellige overtuiging dat zowel de toekomst van de parlementaire democratie als van de ondernemingsgewijze produktie staat of valt met het ontwikkelen van hiertoe geëigende structuren. Een voor de toekomst van het vrije westen uiterst belangrijke taak voor wetenschap, politiek en bedrijfsleven is om in gemeenschappelijke krachtsinspanning dergelijke structuren te ontwerpen.

Keynes heeft reeds in de dertiger jaren een ontwikkeling in de in dit artikel ge. schetste richting voorzien en daarom een belangrijk deel van zijn leven besteed aan het politiek relevant maken van de economische theorie ten einde in nauwe samenhang met de werkelijkheid oplossingen te vinden voor actuele vraagstuk. ken.

Het is een boeiende taak dit werk voort te zetten. Dat hierbij belangrijk werk is weggelegd voor de bedrijfseconomie hoop ik in dit artikel te hebben aangetoond.

\section{Literatuurverwijzingen}

1 M. C. Ellman: Full employment - Lessons from state socialism; rede bij de aanvaarding van het hoogleraarschap in de economie van de centraal geplande economieën aan de Universiteit van Amsterdam op 12 februari 1979

J. M. Keynes: The General Theory of Employment, Interest and Money; London 1964, p. 381.

Brief geciteerd in D. E. Moggridge: Keynes; London 1976, p. 130.

4 Aubrey Jones: Inflation as an industrial problem; in The end of the Keynesian era, edited by R. Skidelsky, London and Basingstoke 1977, p. 50.58.

5 J. M. Keynes: idem, p. 380.

6 C. A. Koopman: Lessen in democratie?; ESB 21.2 .1973 , p. 156.158 en R. F. M. Lubbers, R. Bannink, H. ter Heide en C. A. Koopman: Democratie en efficiency, Amsterdam 1977, p. 29.43.

7 Tibor Scitovsky: The joyless economy; Oxford, London, New York 1977, p. 11.

8 Niels Hammer.Jespersen e.a.: Decision, Planning and Budgeting, OECD 1972, p. 7 e.v.

9 C. A. Koopman: De vele mensbeelden van de econoom; Socialisme en Democratie jrg. 36 no. 2, febr. 1979 , p. 78.87.

10 H. J. Hofstra: Inflatieneutrale belastingheffing; rapport uitgebracht aan de Minister van Financiën, 's-Gra venhage dec. 1977. 
C. A. Koopman: Onderwijsplanning als toepassing van PPBS; Uithoom 1976, p. 187. Idem, p. 100 en 101

Beleidsanalyse, driemaandelijks bericht van de Commissie voor de Beleidsanalyse, 5e jrg. no. 2, p. 15. Idem, 8 e jrg. no. 1 , p. $4 \mathrm{t} / \mathrm{m} 19$.

R. Kerry Turner and Clive Collis: The economics of planning; London and Basingstoke 1977, p. 18 en 19.

Idem, p. 81 en 82.

Rapport van de gemengde ambtelijke werkgroep Onderzoek Uitbreidingsmogelijkheden Hoogovens IJmuiden; Ministerie van Economische Zaken, januari 1976.

Idem, p. 3.

Idem, p. 100.

J. L. Bouma: Ondernemingsdoel en winst; Leiden 1966, p. 25.

Idem, p. 171.

J. L. Bouma: Inleiding tot de tiende, herziene druk van het Leerboek der Bedrijfseconomie deel I door prof. dr. J. L. Meij; Den Haag 1968, p. 36.

Idem, p. 43.

E. Rhenman: Företagsdemokrati och företagsorganisation; Nederlandse vertaling onder de titel Bedrijfs. democratisering en bedrijfsvoering; Alphen a/d Rijn, Brussel 1966, p. 25.

Idem, p. 48 e.v.

Tibor Scitovsky: idem, p. 89 e.v.

P. A. de Ruiter: SIR straks; ESB 24-11-1976, p. 1149.

Zie o.a. H. C. Dekker, C. A. Koopman, S. Matic en M. Požek.Matic: Planning in a Dutch and a Yugoslav Steelworks: a comparative study; Amsterdam 1976, p. 82 e.v. 